\title{
EFFECTS OF HYDROPONIC MEDIA ON FORAGE AND SILAGE QUALITY OF BARLEY (HORDEUM VULGARE L.)
}

\author{
YURTSEVEN, S. ${ }^{*}-$ GÜLER, A. ${ }^{1}-$ SAKAR, E. ${ }^{2}$ \\ ${ }^{1}$ Department of Animal Science, Faculty of Agriculture, Harran University \\ 63300 Şanlıurfa, Turkey \\ ${ }^{2}$ Department of Horticulture, Faculty of Agriculture, Harran University \\ 63300 Şanliurfa, Turkey \\ *Corresponding author \\ e-mail: syurtseven@harran.edu.tr; phone: +90-414-318-3474; fax: +90-414-318-3274 \\ (Received $3^{\text {rd }}$ Oct 2019; accepted $8^{\text {th }}$ Jan 2020)
}

\begin{abstract}
This study was carried out to investigate the effects of different substrates (barley+straw and barley+dry olive pulp) on the feed value of barley plants produced in a hydroponic system. In addition, germination of barley was tested in experiment 2 for silage quality. For this purpose, barley was harvested on the 7th day of the experiment. Nutrient contents of plant samples were determined. Dry matter content of the fodders increased significantly with the addition of straw $(\mathrm{P}<0.01)$, while the ash, ADF and NDF contents significantly increased $(\mathrm{P}<0.01)$ with the addition of dry olive pulp (prina) ratio. In trial 2 , the addition of straw and dry olive pulp increased the dry matter content of the silage while the straw increased the $\mathrm{pH}$ of silage $(\mathrm{P}<0.01)$. The contribution of dry olive pulp increased total ash, ADF and NDF values in silage. Protein levels did not differ in either trials $(\mathrm{P}>0.05)$. The results revealed that the use of straw is useful in preventing the negative effect of excess water in germination environment. In addition, relative feed value (RFV) and digestible dry matter (DDM) criteria of feeds were quite satisfactory. Nutrient content and other quality criteria of feed indicated that hydroponic barley is a favorable silage material with base materials, though wheat straw was superior to dry olive pulp.
\end{abstract}

Keywords: olive pulp, hydroponic farming, germination, animal feed, straw

\section{Introduction}

Supply of quality fresh green feed is one of the major challenges for animal breeders in hot summer months. Traditional fresh green forage production requires land, labor and a significant amount of water. Hydroponic feed production technique converts an energy feed such as barley grain into a green feed and requires less soil, water and labor, and enables production at any time of the year. In addition, the fresh forage produced in hydroponic systems are claimed to have high digestibility (Chung et al., 1989; Islam and Jalal, 2016). Hydroponic systems, unlike other production systems, are based on the reuse of water; thus, consumes $87 \%$ less water for the same amount of feed production (Al-Karaki and Al-Moani, 2011). Corn is less preferred because it does not germinate as easily as barley. Wheat and rye are not preferred compared to barley because wheat is consumed as human food. Rye seeds are very small, an efficient germination cannot be achieved in one week and is more suitable for grazing on pasture. Rye grass is not also preferred because it is not a plant that is consumed as grain like barley. This production model is suitable and economical for some annual plants consumed as grain. Barley is most commonly used cheap source in hydroponic systems and can be obtained easily. The harvest is very easy and practical, so it is possible to harvest every day of the year and there is no need for stocking. 
Studies conducted on the hydroponic feed production revealed no loss of dry matter or no significant changes in nutrient content (Peer and Leeson, 1985). In contrast, some reports indicated that high humidity in hydroponic fodder adversely affects the feed consumption of animals and excessive moisture causes mold problems in hydroponic production. Therefore, Tudor et al. (2003) recommended the addition of straw during consumption to decrease the moisture and increase dry matter content.

Total of 4500 tons of olive was produced in Sanliurfa province, Turkey in 2016 (TUIK, 2016). Olive pulp is a major byproduct and environmental pollutant of oil extraction process and approximately 70-80\% of processed olives turns into olive pulp which corresponds to 3500 tons per year. Olive pulp consists of shell, seed and crushed fruit and can be utilized as a germination medium due to the high nutrient contents. Sansoucy (1985) reported that olive pulp may contain as high as 75 to $80 \%$ dry matter, 3 to $5 \%$ crude ash, 35 to $50 \%$ crude cellulose, 5 to $10 \%$ crude protein and 8 to $15 \%$ crude oil as dry matter basis (Sansoucy, 1985).

Moisture content of hydroponic feed can be reduced, and nutrient losses can be minimized using agricultural wastes such as straw or dry olive pulp in hydroponic plant production Dry olive pulp can also provide some nutrients to the germination environment. This study was aimed to cope with high moisture problem in soilless barley production and to reduce nutrient losses in germinated barley by using olive pulp and straw.

\section{Material and Method}

The experiment was conducted during April 2014 at the Faculty of Agriculture, Harran University, Turkey. The study consisted of two different germination experiments in controlled room conditions under natural lighting at temperatures varying between 16 and $35^{\circ} \mathrm{C}$ throughout the experiments.

\section{Experiment 1}

The seeds of barley (Hordeum vulgare L.), with $88 \%$ dry matter and $11 \%$ crude protein used as the material in the experiments were purchased from a local grain market and kept in a cold environment $\left(4^{\circ} \mathrm{C}\right)$ to ensure the germination (vernalization) a day before the start of the experiment. The barley used was the local Ayhan variety of malting barley in this study. The germination system was adapted from the system applied by Al-Karaki and Al-Hashimi (2012). Germination experiment was conducted in aluminum trays with the dimensions of $19 \times 9 \times 3 \mathrm{~cm}$. The first experiment comprised only of the germination of barley and the second experiment was on quality of silage prepared by the germinated barley.

The barley grains, which were kept in the cold for one day, were washed and filtered to remove dust and dirt. In this way, seeds were thoroughly cleaned and disinfected. Barley grains were kept in water for one day to soften the seeds; thus, facilitated the germination. The soften seeds were scattered on trays for the germination.

The effect of three different treatments on germination of barley seeds was investigated. The treatments were control (C, only barley), wheat straw (WB) and dry olive pulp (PB). In control treatment, barley seeds were placed in the trays without any supportive material. Barley seeds were covered with wheat straw in WB and with dry olive pulp in PB treatments. WB and PB were taken up to cover the barley seeds and approximately $15 \mathrm{~g}$ for straw and $50 \mathrm{~g}$ for dry olive pulp. The aim of experiment 1 was 
to investigate the germination power and the effects of wheat straw and dry olive pulp on nutritional value of germinated barley. Wet weight of barley was used to determine the amount of seeds to be sown. Accordingly, $60 \mathrm{~g}$ of wet barley seeds were weighed into $0.017 \mathrm{~m}^{2}$ trays and left for germination. The amount of seeds corresponded to $3550 \mathrm{~g}$ wet barley per $\mathrm{m}^{2}$, which was equivalent to $1000 \mathrm{~g}$ dry barley grain per $\mathrm{m}^{2}$ (Fig. 1).

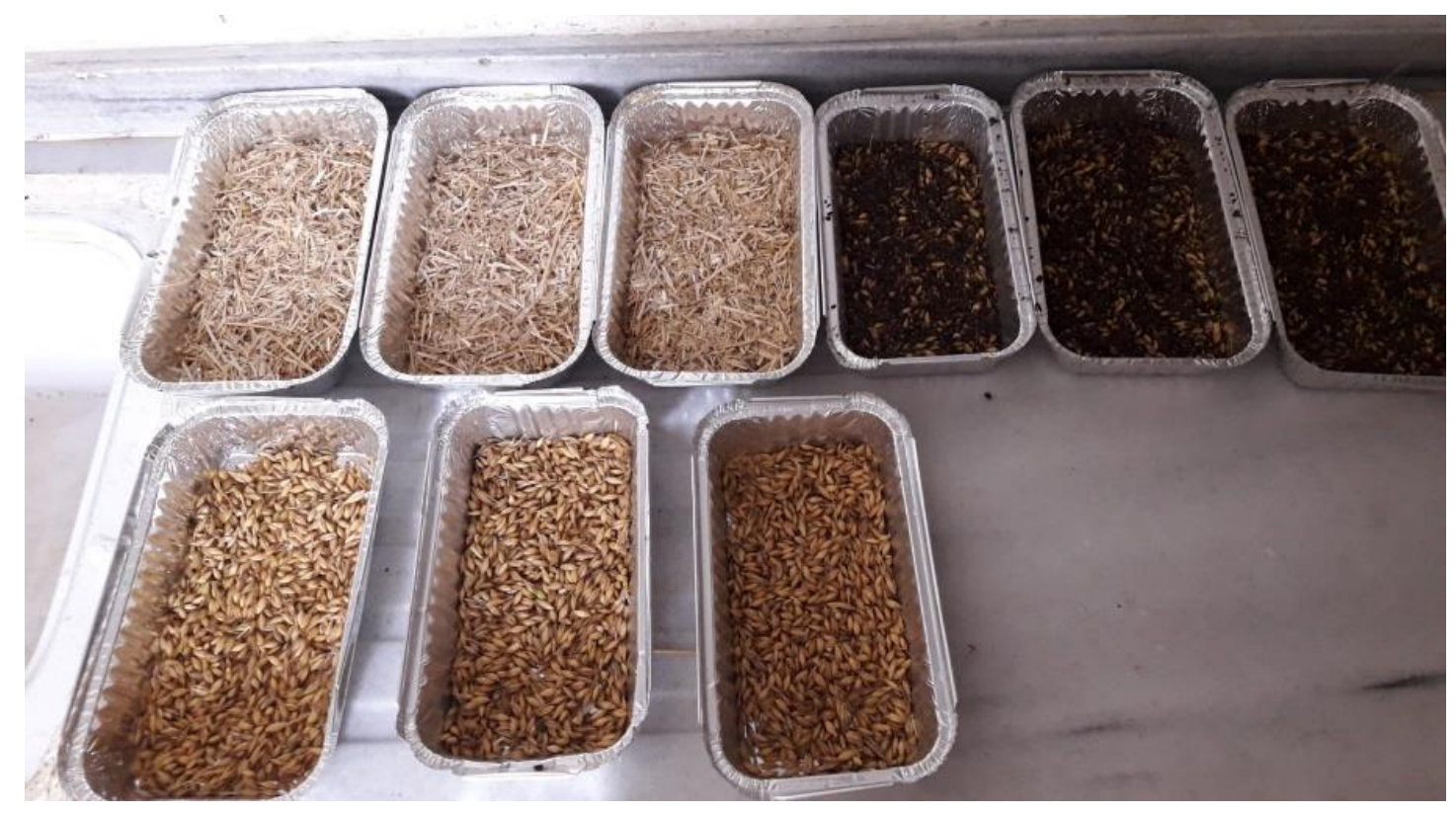

Figure 1. Barley germination patterns in hydroponics (top right: with dry olive pulp (PB); top left: with wheat straw (WB) and bottom: barley (Control; $C)$ )

The seeds were carefully placed into floor of the germination trays up to a height corresponding to finger thickness and covered the whole floor of the trays. Seeds were covered by straw and dry olive pulp to reduce the moisture in hydroponic feed. The trays were placed close to the windows for natural lighting throughout the germination. Temperature and humidity of the environment were recorded during the germination. The temperature varied between 16 and $35^{\circ} \mathrm{C}$ and humidity ranged from 20 to $66 \%$ during the trial. Since water accumulation in the system causes the formation of mold, excess water had to be drained. Therefore, the trays were placed with 1-2\% inclination to discharge the excess water. Plants were watered twice a day (morning and afternoon) during the germination process, avoiding over watering and providing good drainage. Irrigation was continued until the water covered all the seeds.

Dense green cover and matted/entangled root accumulation in the tray were the criteria of germination success. The experiment 1 was terminated after 7 days, and the trays were weighed on the morning of 8th day. The biomass harvested in each treatment was measured and green fodder yield was determined. After the germination, straw and dry olive pulp was removed. Plant yield/seed ratio, grass yield, crude protein ratio, protein yield, plant height and root structure were determined. Fresh and dry weights of harvested plants were recorded. Plant samples was dried to a constant weight in an oven at $55^{\circ} \mathrm{C}$ for two 48 hours. The dried samples were ground to pass through $1 \mathrm{~mm}$ sieve for crude protein ratio and protein yield analysis. 


\section{Experiment 2}

Barley seedlings of C, WB and PB treatments were harvested on day 7 and silage of each treatment was prepared in air tight nylon bags to determine quality traits of silages (Fig. 2). Silage bags were kept for 60 days, and the bags were opened, and samples were analyzed for quality traits. The $\mathrm{pH}$, color, odor and appearance of silage samples were determined, and dry mater contents were measured. Dry matter yield, crude ash, acid detergent fiber (ADF), neutral detergent fiber (NDF) and protein contents were analyzed in air dried silage samples. The NDF and ADF contents were determined by ANKOM-200 fiber analyzer using the method of Van Soest et al. (1991). Nitrogen content was analyzed by Kjeldahl method. Flieg score was calculated using the relationship between $\mathrm{pH}$ of silage and dry matter content. There is a high correlation between the silo feed and quality calculated according to following equation (Kara et al., 2009).

Flieg score $:=205+(2 *$ silage dry matter, $\%)-40 * p H$ of silage feed (Eq. 1$)$

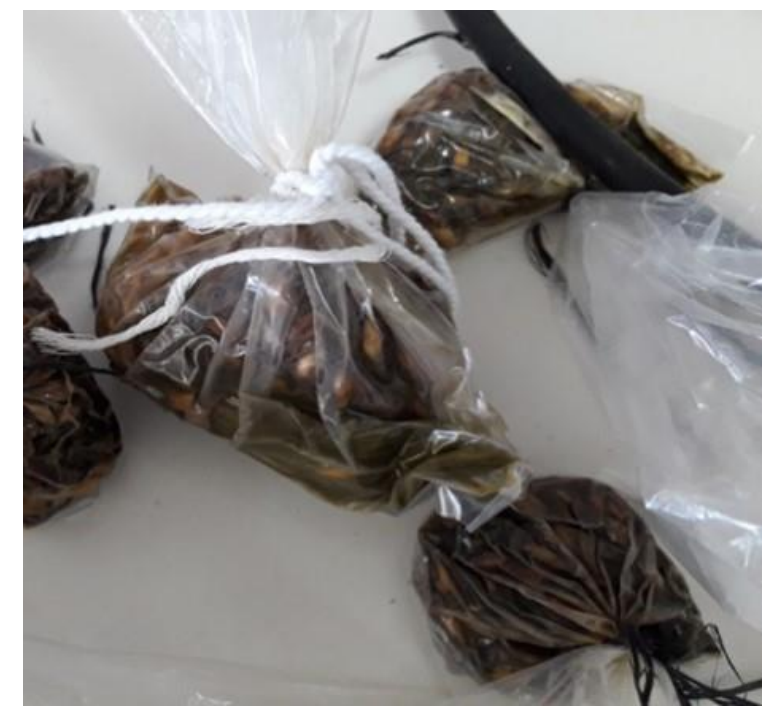

Figure 2. Making silage of germinated hydroponic product in nylon bags

\section{Estimating the Relative Feed Value, Digestible Dry Matter and Dry Matter Intake}

Relative Feed Value (RFV) is an index that estimates the digestible dry matter (DDM) of samples from the ADF and calculates the dry matter intake (DMI) potential (as a percentage of body weight, BW) from NDF. The index is then calculated as DDM multiplied by DMI and divided by 1.29 (Stallings, 2006).

$$
\begin{gathered}
\text { Digestible Dry Matter }(D D M)=88.9-(0.779 * \% A D F) \\
\text { Dry matter intake }(D M I)(\% \text { of } B W)=120 /(\% N D F) \\
\text { Relative feed value }(R F V)=(D D M * D M I) / 1.29
\end{gathered}
$$




\section{Statistical Analysis}

The data were analyzed by one-way analysis of variance (ANOVA) test according to the randomized plot design with three treatments (SPSS, 2003). Experiment 1 and 2 were evaluated under 3 different groups by drying in trial 1 and silage in trial 2. Each experiment was analyzed separately; each treatment $(\mathrm{C}, \mathrm{WB}$ and $\mathrm{PB})$ had three replications. However, RFV, DDM and DMI values of the experiment 1 and 2 were analyzed together. Thus, the effects of different treatments (such as silage application) on feed value were assessed together.

\section{Results}

The images of green parts and root formation one week after the germination were shown in Fig. 3. Yield and some characteristics of germinated barley in experiment 1 were presented in Table 1. Forage yield barley with different hydroponic medium treatments ranged from 1056 to $1315 \mathrm{~g} \mathrm{~m}^{-2}$ and the highest green yield was obtained in WB treatment $(\mathrm{P}<0.01)$.

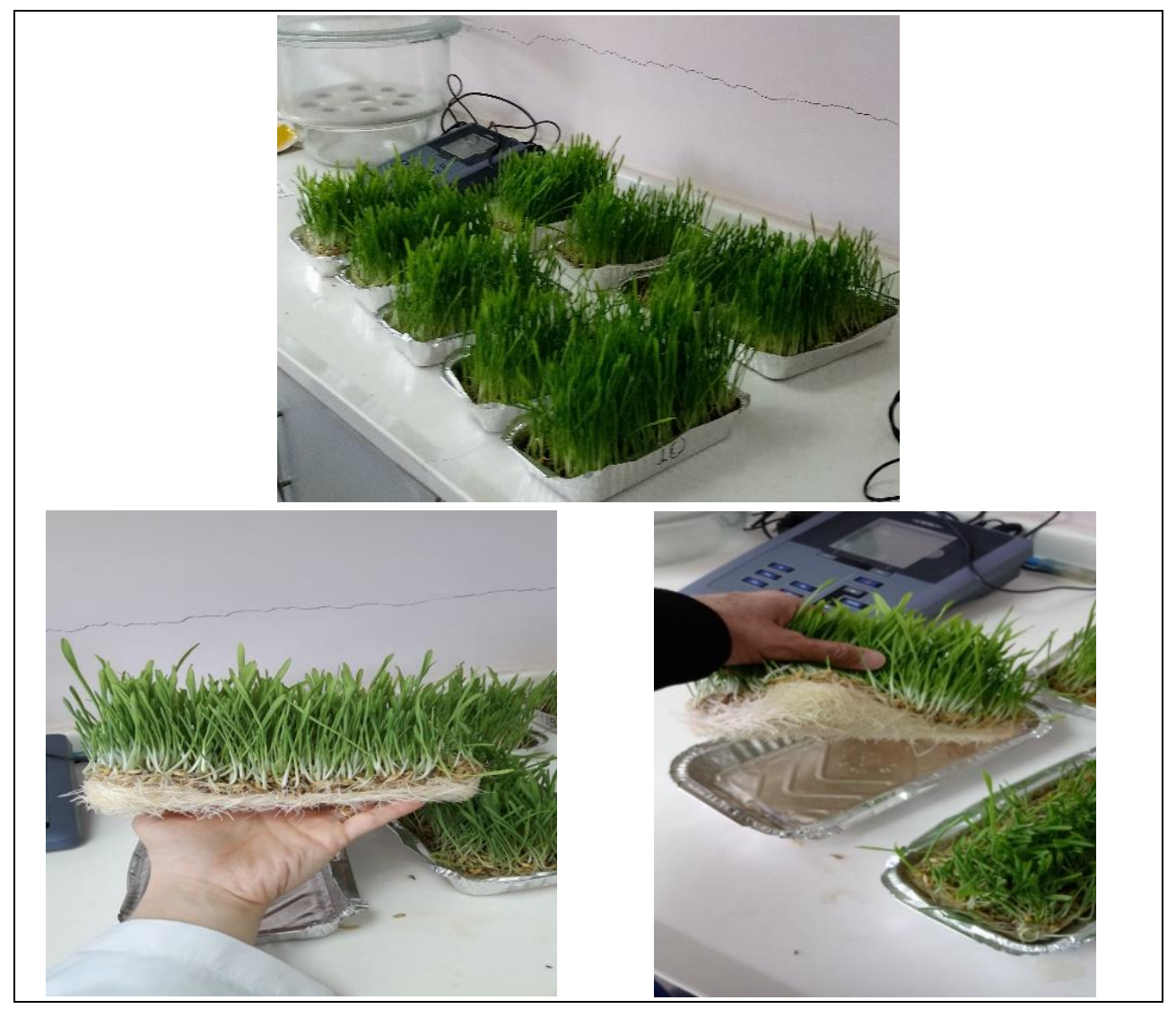

Figure 3. Green parts and root formation of barley plants one week after the germination

Mean dry matter content in WB treatment was significantly $(\mathrm{P}<0.01)$ higher than that in $\mathrm{C}$ and $\mathrm{PB}$ treatments. Total ash, $\mathrm{ADF}$ and NDF in PB treatment were higher than those in $\mathrm{C}$ and $\mathrm{WB}(\mathrm{P}<0.01)$. Dry matter yield, total $\mathrm{N}$ and crude protein content were not significantly different among different treatments (Table 1). 
Table 1. Some nutrient contents of barley grown in the hydroponic system (Experiment 1)

\begin{tabular}{|c|c|c|c|c|c|}
\hline & & Average & Standard dev. & Standard error & Sig. \\
\hline \multirow{3}{*}{ Dry matter-biomass, [\%] } & $\mathrm{C}$ & $21.25^{\mathrm{ab} \beta}$ & 3.29 & 0.92 & 0.006 \\
\hline & WB & $25.75^{\mathrm{b}}$ & 3.45 & 0.99 & \\
\hline & PB & $16.52^{\mathrm{a}}$ & 0.44 & 0.06 & \\
\hline \multirow{3}{*}{$\begin{array}{c}\text { Dry matter, in air-dried biomass } \\
{[\%]^{*}}\end{array}$} & $\mathrm{C}$ & $94.05^{\mathrm{b}}$ & 2.16 & 0.72 & 0.001 \\
\hline & WB & $89.88^{\mathrm{a}}$ & 1.59 & 0.50 & \\
\hline & $\mathrm{PB}$ & $96.02^{c}$ & 1.26 & 0.39 & \\
\hline \multirow{3}{*}{ Productivity-dry yield $\left[\mathrm{g} \mathrm{m}^{-2}\right]$} & $\mathrm{C}$ & $1084.7^{\mathrm{a}}$ & 141.3 & 63.2 & 0.01 \\
\hline & WB & $1315.3^{b}$ & 151.9 & 67.9 & \\
\hline & $\mathrm{PB}$ & $1056.1^{\mathrm{a}}$ & 53.1 & 23.9 & \\
\hline \multirow{3}{*}{$\begin{array}{l}\text { Dry matter yield, [g per g dry } \\
\text { seed] }\end{array}$} & $\mathrm{C}$ & 2.56 & 0.70 & 0.40 & 0.22 \\
\hline & WB & 3.12 & 0.33 & 0.19 & \\
\hline & $\mathrm{PB}$ & 2.28 & 0.49 & 0.28 & \\
\hline \multirow{3}{*}{ Total ash, $[\%]$} & $\mathrm{C}$ & $4.21^{\mathrm{ab}}$ & 2.00 & 0.66 & 0.02 \\
\hline & WB & $3.12^{\mathrm{a}}$ & 2.28 & 0.72 & \\
\hline & $\mathrm{PB}$ & $5.94^{\mathrm{b}}$ & 1.81 & 0.57 & \\
\hline \multirow{3}{*}{ ADF-dry matter basis, [\%] } & $\mathrm{C}$ & $16.53^{\mathrm{a}}$ & 0.86 & 0.43 & 0.001 \\
\hline & WB & $14.77^{\mathrm{a}}$ & 1.46 & 0.73 & \\
\hline & $\mathrm{PB}$ & $29.81^{b}$ & 1.37 & 0.68 & \\
\hline \multirow{3}{*}{ NDF-dry matter basis, [\%] } & $\mathrm{C}$ & $33.83^{b}$ & 0.80 & 0.40 & 0.001 \\
\hline & WB & $40.46^{\mathrm{a}}$ & 2.37 & 1.18 & \\
\hline & $\mathrm{PB}$ & $47.77^{\mathrm{c}}$ & 1.83 & 0.91 & \\
\hline \multirow{3}{*}{$\mathrm{N}$ - dry matter basis, [\%] } & $\mathrm{C}$ & 1.72 & 0.14 & 0.10 & 0.32 \\
\hline & WB & 1.12 & 0.07 & 0.06 & \\
\hline & PB & 1.73 & 0.64 & 0.45 & \\
\hline \multirow{3}{*}{$\begin{array}{c}\text { Crude protein-dry matter basis, } \\
{[\%]}\end{array}$} & $\mathrm{C}$ & 10.77 & 0.91 & 0.64 & 0.32 \\
\hline & WB & 8.05 & 0.50 & 0.35 & \\
\hline & $\mathrm{PB}$ & 10.85 & 4.00 & 2.83 & \\
\hline \multirow{3}{*}{ Germination plant length, $[\mathrm{cm}]$} & $\mathrm{C}$ & 11.46 & 1.26 & 0.73 & 0.21 \\
\hline & WB & 11.0 & 0.45 & 0.26 & \\
\hline & $\mathrm{PB}$ & 12.46 & 0.83 & 0.48 & \\
\hline
\end{tabular}

*: Determined in air dried samples after reaching to a constant weight.

C: Control (only barley), WB: barley covered with wheat straw, PB: barley covered with dry olive pulp, ADF: Acid detergent fiber, NDF: Neutral detergent fiber, Sig: significance level, ${ }^{\beta}$ : Means followed by different letters are significantly different by each other at $\mathrm{P}<0.05$ level of significance

Some characteristics of barley silage produced in hydroponic system with different cover materials in experiment 2 were presented in Table 2. Mean $\mathrm{pH}$ value and dry matter content of silage were higher in $\mathrm{WB}$ treatment than that in $\mathrm{C}$ and $\mathrm{PB}$ treatments $(\mathrm{P}<0.01)$. $\mathrm{ADF}$ and NDF content of silage samples were significantly higher $(\mathrm{P}<0.01)$ in $\mathrm{PB}$ treatment than that in $\mathrm{C}$ and $\mathrm{WB}$ treatments. Total $\mathrm{N}$ and crude protein content of silage samples were not significantly different among different treatments (Table 2).

The RFV values of both experiments were analyzed together in experiment 1 and 2 to assess the overall effect of cover materials and feed value of silage. The lowest DMI, DDM and RFV values were obtained in the PB treatments $(\mathrm{P}<0.01)$, while the highest values of RFV and DMI were observed in the WB treatments. 
Table 2. Some characteristics of barley silage produced in hydroponic system with different cover materials (Experiment 2)

\begin{tabular}{|c|c|c|c|c|c|}
\hline & & Average & Standard dev. & Standard error & Sig. \\
\hline \multirow{3}{*}{$\mathrm{pH}$} & $\mathrm{C}$ & $4.11^{\mathrm{a} \beta}$ & 0.19 & 0.11 & 0.02 \\
\hline & WB & $4.70^{b}$ & 0.15 & 0.09 & \\
\hline & $\mathrm{PB}$ & $4.11^{\mathrm{a}}$ & 0.26 & 0.15 & \\
\hline \multirow{3}{*}{ Flieg score } & $\mathrm{C}$ & $80.15^{\mathrm{a}}$ & 8.04 & 4.64 & 0.06 \\
\hline & WB & $83.39^{\mathrm{ab}}$ & 8.43 & 4.86 & \\
\hline & $\mathrm{PB}$ & $97.09^{\mathrm{b}}$ & 5.96 & 3.44 & \\
\hline \multirow{3}{*}{ Dry matter-biomass, [\%] } & $\mathrm{C}$ & $19.16^{\mathrm{a}}$ & 8.69 & 4.34 & 0.02 \\
\hline & WB & $33.86^{b}$ & 1.83 & 1.05 & \\
\hline & $\mathrm{PB}$ & $32.98^{\mathrm{b}}$ & 2.58 & 1.49 & \\
\hline \multirow{3}{*}{ Total ash, $[\%]$} & $\mathrm{C}$ & 0.97 & 1.37 & 0.79 & 0.52 \\
\hline & WB & 1.42 & 1.60 & 1.13 & \\
\hline & $\mathrm{PB}$ & 10.57 & 16.83 & 9.71 & \\
\hline \multirow{3}{*}{ ADF-dry matter basis, [\%] } & $\mathrm{C}$ & $17.49^{\mathrm{a}}$ & 2.19 & 1.09 & 0.001 \\
\hline & WB & $18.29^{\mathrm{a}}$ & 1.54 & 0.77 & \\
\hline & $\mathrm{PB}$ & $30.94^{\mathrm{b}}$ & 3.86 & 1.93 & \\
\hline \multirow{3}{*}{ NDF-dry matter basis, [\%] } & $\mathrm{C}$ & $34.77^{\mathrm{a}}$ & 2.53 & 1.26 & 0.001 \\
\hline & WB & $33.67^{\mathrm{a}}$ & 0.85 & 0.42 & \\
\hline & $\mathrm{PB}$ & $40.99^{b}$ & 1.22 & 0.61 & \\
\hline \multirow{3}{*}{$\mathrm{N}-\mathrm{dry}$ matter basis, [\%] } & $\mathrm{C}$ & 1.44 & 0.26 & 0.19 & 0.92 \\
\hline & WB & 1.13 & 0.06 & 0.07 & \\
\hline & $\mathrm{PB}$ & 1.46 & 0.007 & 0.005 & \\
\hline \multirow{3}{*}{ Crude protein-dry matter basis, [\%] } & $\mathrm{C}$ & 9.04 & 1.68 & 1.18 & 0.92 \\
\hline & WB & 8.15 & 0.52 & 0.35 & \\
\hline & $\mathrm{PB}$ & 9.17 & 0.04 & 0.03 & \\
\hline
\end{tabular}

C: Control, barley only, WB: Barley covered with wheat straw, PB: Barley covered with dry olive pulp, Sig: significance level, ${ }^{\beta}$ : Means followed by different letters are significantly different by each other at $\mathrm{P}<0.05$ level of significance

\section{Discussion}

In contrast to Fazaeli et al. (2012) and Kılıç (2016) who stated that dry matter content of the hydroponic green feed does not substantially change compared to the grain form of the same feed (88\%), the results showed that dry matter production was significantly improved in a short period of time ( 7 days). This is one of the important outcomes of our study. Although the cover materials were removed after the germination, dry matter content (90 and 96\%, respectively) in WB and PB treatments was higher than that in control (barley-only) treatment (89.8\%). The improvement in dry matter content was even more pronounced in the PB treatment. The highest dry matter yield was obtained in straw supported hydroponic barley; however, no significant change was observed in dry matter yield of control and PB treatments. The results revealed that contribution of straw cover on germination and subsequent growth of barley as indicated by the dry matter yield was greater compared to that of olive pulp.

Straw-supported hydroponic forage production improved the efficiency of water use. The productivity was higher in WB treatment compared to control and PB treatments. This result could be attributed to the high level of dry matter content in WB treatment 
which absorbed higher water and provided a more suitable environment for germination. The results showed that straw can be an important cover material to eliminate the mold problem caused by high humidity in hydroponic forage production.

Crude protein content of fodder in all treatments was similar that could be related to the removal of straw cover material from the medium after the germination, and low protein content of olive pulp. Although the cover materials were removed from the environment after the germination, some of the dry olive pulp may have remained in the environment as dust or thinner form. Total ash, ADF and NDF contents in PB treatment were higher compared to the control. This could be ascribed by the high level of ash, ADF and NDF contents in dry olive pulp. Therefore, total ash content of dry olive pulp caused an increase in ash level of hydroponic barley fodder.

Plant height and root development were not significantly different among the treatments. The highest plant height during the 7-day of germination period was $12 \mathrm{~cm}$. The results showed that the cover materials did not affect the growth rate, however, they could suppress the excess moisture occurring in the hydroponic environment. Gunasekaran et al. (2018) used plastic trays with cover materials to germinate barley seeds in hydroponic barley cultivation. Like the results on growth rate reported in our study, Gunasekaran et al. (2018) stated that the cover material did not affect the growth rate. However, they found that paddy husk and bagasse provided the highest forage yield. The researchers placed the cover materials on the floor of trays and stated that the entangled structure between the roots and the base material caused the waste of feed. However, the cover materials were used to cover the barley seeds in the trays (Fig. 1); thus, matted structure problem between the roots and the cover material was not observed in our study.

The study did not focus on measuring seed density per square meter. However, the seeding rate used was about $1000 \mathrm{~g} \mathrm{~m}^{-2}$ which resulted in a certain amount of dry yield increase and no fungal contamination. Naik et al. (2015) reported that high seed density increased the chances of microbial contamination in the root mat, which in turn affected the growth of the sprouts. The fodder yield obtained from $1000 \mathrm{~g}$ dry seed $\mathrm{m}^{-2}$ density for 7 days was $1315 \mathrm{~g}$. Al-Karaki and Al-Hashimi (2012) used $400 \mathrm{~g} \mathrm{~m}^{-2}$ seeding rate for barley and obtained $1122 \mathrm{~g}$ dry yield $\mathrm{m}^{-2}$ for 8 days not 7 days.

The $\mathrm{pH}$ value and dry matter content in WB treatment were significantly increased during silage making, and this was quite favorable for silage quality (Table 2). The results revealed that the use of straw cover material during germination caused drier germination environment which had an effect on $\mathrm{pH}$ increase. The changes ADF and NDF contents were significantly important and related to the use of dry olive pulp as the cover material. The cell wall components of dry olive pulp increased the cell wall of the silage produced in PB treatments. The ash content of barley silages was increased in PB treatments during silage due to the high ash content of dry olive pulp (Table 2). The cell wall deposition, such as the percentage of NDF and ADF probably, increased the ash content of silage in PB treatment. Reasonable silages in terms of Flieg score were produced in WB and PB treatments due to the contribution of straw or dry olive pulp to ambient $\mathrm{pH}$ and dry matter level.

The highest RFV and DMI values were observed in the WB treatments where straw was used as the cover material (Table 3). The animal consumption of some fodders may negatively be affected due to the high moisture content of the fodders. Therefore, Fazaeli et al. (2012) and Tudor et al. (2003) suggested adding some hay to decrease the moisture and raise the dry matter contents of fodder. Mean DMI value of green feed in WB 
treatment was higher in our study. The RFV value is used generally to compare similar forages for the consumption and digestion (Wettstein et al., 2000). The RFV values were found as "Prime" for all fodders according to the Quality Grading Standard assigned by the Hay Market Task Force of American Forage and Grassland Council. Since DDM value is affected from ADF content of feeds, higher DDM value in WB treatments can also be attributed to the lower ADF content (Robinson, 2005).

Table 3. The RFV, DDM and DMI values of samples from Experiment 1 and 2

\begin{tabular}{|c|c|c|c|c|c|c|c|c|}
\hline \multirow{3}{*}{$\begin{array}{c}\text { Parameters } \\
\text { of feed evaluation }\end{array}$} & \multicolumn{8}{|c|}{ Samples } \\
\hline & \multicolumn{3}{|c|}{ Experiment 1} & \multicolumn{3}{|c|}{ Experiment 2} & \multirow[b]{2}{*}{ SEM } & \multirow[b]{2}{*}{ Sig. } \\
\hline & $\mathrm{C}$ & WB & PB & $\mathrm{CS}$ & WB & PB & & \\
\hline DDM, [\%] & $77.4^{\mathrm{c} \beta}$ & $76.0^{\mathrm{bc}}$ & $65.7^{\mathrm{a}}$ & $75.3^{\mathrm{bc}}$ & $74.6^{\mathrm{b}}$ & $64.8^{\mathrm{a}}$ & 0.7 & 0.01 \\
\hline DMI, [\% BW] & $3.0^{\mathrm{b}}$ & $3.5^{\mathrm{c}}$ & $2.5^{\mathrm{a}}$ & $3.5^{\mathrm{c}}$ & $3.6^{\mathrm{c}}$ & $2.9^{\mathrm{b}}$ & 0.1 & 0.01 \\
\hline RFV & $178.5^{\mathrm{c}}$ & $209.1^{\mathrm{d}}$ & $128.0^{\mathrm{a}}$ & $202.2^{\mathrm{d}}$ & $206.3^{\mathrm{d}}$ & $147.1^{\mathrm{b}}$ & 4.4 & 0.01 \\
\hline
\end{tabular}

RFV: Relative feed value, DDM: Digestible dry matter (\%of body weight), DMI: Dry matter intake (\%of body weight, C: Control (only barley germination), WB: barley covered with wheat straw, PB: barley covered with dry olive pulp, ${ }^{\beta}$ : Means followed by different letters are significantly different by each other at $\mathrm{P}<0.05$ level of significance

\section{Conclusion}

Feed analysis showed that dry matter protein content of the barley fodder produced in hydroponic system increased; however, the protein value did not significantly differ from the barley grain seeds as a percent of dry matter. The results concluded that barley is a good grain for fodder and silage production under hydroponic conditions. In addition, the green and silage feed values obtained are satisfactory and better-quality hydroponics can be produced in the germination environments supported by cover materials (straw and dry olive pulp). The results revealed that wheat straw was more effective than dry olive pulp which had no significant effect on all parameters compared to control in experiment 1 and 2. This production model is suitable for some annual plants consumed as grain and it is not a suitable production method for plants with very small seed. On the other hand, since this type of production is not effective and economical for perennial plants, it would be useful to conduct studies on some other annual forage plants.

Acknowledgements. This work was supported by the Harran University Research Committee under Grant [HUBAB-Research Projects Unit, Şanlıurfa, Turkey. Project no. -2018/17253].

\section{REFERENCES}

[1] Al-Karaki, G. N., Al-Momani, N. (2011): Evaluation of some barley cultivars for green fodder production and water use efficiency under hydroponic conditions. - Jordan Journal of Agricultural Sciences 7: 448-456.

[2] Al-Karaki, G. N., Al-Hashimi, M. (2012): Green fodder production and water use efficiency of some forage crops under hydroponic conditions. - International Scholarly Research Network ISRN Agronomy 2012: 1-5.

[3] Chung, T. Y., Nwokolo, E. N., Sim, J. S. (1989): Compositional and digestibility changes in sprouted barley and canola seeds. - Plant Foods for Human Nutrition 39: 267-278. 
[4] Fazaeli, A., Golmohammadi, H. A., Tabatabayee, S. N., Asghari-Tabrizi, M. (2012): Productivity and nutritive value of barley green fodder yield in hydroponic system. - World Applied Sciences Journal 16(4): 531-539.

[5] Gunasekaran, S., Bandeswaran, C., Valli, C. (2018): Low-cost hydroponic fodder production technology for sustainable livestock farming during fodder scarcity. - Current Science 116: 526-528.

[6] Islam, R., Jalal, N. (2016): Effect of seed rate and water level on production and chemical analysis of hydroponic fodder. - European Academic Research 4(8): 6724-6753.

[7] Kara, B., Ayhan, V., Akman, Z., Adiyaman, E. (2009): Determination of silage quality, herbage and hay yield of different triticale cultivars. - Asian Journal Animal Veterinary Advances 4(3): 167-171.

[8] Kılıç, U. (2016): Kaba yem üretiminde hidroponik tarım sistemleri. - Türk Tarım Gıda Bilim ve Teknoloji Dergisi 4: 793-799.

[9] Naik, P. K., Swain, B. K., Swain, N. P., Singh, N. P. (2015): Review-production and utilisation of hydroponics fodder. - Indian Journal Animal Nutrition 32(1): 1-9.

[10] Peer, D. J., Leeson, S. (1985): Nutrient content of hydroponically sprouted barley. - Animal Feed Science and Technology 13: 191-202.

[11] Robinson, P. H. (2005): Estimating alfalfa hay and corn silage energy levels, UC Davis Equations using NDF, ADF. - Proceedings, 31st California Alfalfa and Forage Symposium, 12-13 December, 2001, Modesto, CA, UC.

[12] Sansoucy, R. (1985): Olive by-products for animal feed. Review. - FAO Animal Production and Health Paper 43, Food and Agriculture Organization of the United Nations, Rome.

[13] Stallings, C. C. (2006): Relative Feed Value (RFV) and Relative Forage Quality (RFQ). Nutrition \& Forage Quality 540: 231-3066.

[14] Tudor, G., Darcy, T., Smith, P., Shallcross, F. (2003): The intake and live weight change of drought master steers fed hydroponically grown, young sprouted barley fodder (Auto Grass). - Department of Agriculture Western Australia.

[15] TUIK (2016): Plant production statistics. - Agricultural Statistics Database. Turkish Statistical Institute, Ankara.

[16] Van Soest, P., Robertson, J., Lew1s, B. A. (1991): Methods for dietary fiber, Neutral Detergent Fiber and Non-starch Polysac charides in relation to animal nutrition. - Journal of Dairy Science 74(10): 3583-3597.

[17] Wettstein, H. R., Machmuller, A., Kreuzer, M. (2000): Effects of raw and modified canola lecithins compared to canola oil, canola seed and soy lecithin on ruminal fermentation measured with rumen simulation technique. - Animal Feed Science and Technology 85: 153-169. 